\title{
Continuing Environmental Change - An Example from Nova Scotia
}

\author{
EDMUND S. TELFER
}

Scientist Emeritus, Canadian Wildlife Service, Environment Canada

Current address: 3582-42 Street, Edmonton, Alberta, T6L 5A1 Canada

Telfer, Edmund S. 2004. Continuing environmental change - an example from Nova Scotia. Canadian Field-Naturalist 118(1): 39-44.

Information from personal experience, from community elders and published literature served as a basis for evaluating environmental changes in the District of North Queens and adjacent areas of Southwestern Nova Scotia over the past century. Major events included disappearance of the Caribou (Rangifer tarandus), the arrival of White-tailed Deer (Odocoileus virginianus), the severe reduction of Canada Yew (Taxus canadensis), disappearance of Lynx (Lynx canadensis), a major dieoff of Striped Skunks (Mephitis mephitis), decline of American Beech (Fagus grandifolia), the loss of mature birch (Betula spp.), the severe reduction of Moose (Alces alces), the arrival of the American Dog Tick (Dermacentor variabilis) and Coyotes (Canis latrans), and the restoration of Beaver (Castor canadensis). The proximate cause of many of those changes were plant and animal disease, while the ultimate causes were naturally occurring animal range expansion and human impacts. The warming of the climate over the past 150 years probably played a role. The nature and timing of the events could not have been predicted.

Key Words: Nova Scotia, plant and animal diseases, change in biota, climate change, adaptive management.

Here, I present and discuss an example of long-term environmental change. It is a narrative account of changes in the occurrence of some mammals and plants in my home area, the District of North Queens, and surrounding portions of the interior of southwestern Nova Scotia. I personally observed these changes or heard about them from my father and other community elders and further document them by reference to the available literature. I discuss the changes in the light of current resource management philosophy. Since my father was born in 1882 and was a teenager in the 1890s, the changes noted cover a century.

The District of North Queens lies in the interior of the southwestern peninsula of Nova Scotia and is centred at approximately $65^{\circ} 09^{\prime} \mathrm{W}$ and $44^{\circ} 18^{\prime} \mathrm{N}$. It is an area of scattered farms and homesteads where the population has subsisted for 200 years on a mix of agriculture and forestry. The district contains the western portion of a swarm of glacially-formed drumlin hills that occur in Lunenburg and Queens counties (Roland 1982). Drumlins provide arable land but comprise a small proportion of the land area. Most of the district is rocky, forested terrain that, even where cultivatable and productive, was difficult for early settlers to clear. The remainder of the interior of western Nova Scotia is a complex of water bodies, bogs, fens, barrens and stony soils supporting Acadian forests of mixed conifers and deciduous tree species (Rowe 1972). When my father was born the area contained considerably more crop agriculture and improved pasture than today. For the County of Queens as a whole, approximately 30000 acres (12 $140 \mathrm{ha}$ ) were under agriculture in 1870 (Canada 1871). This area dropped to 7410 acres (2999 ha) by 1966 (Nova Scotia 1966). However, those were small proportions of the total area, $4.4 \%$ in 1870 and $1.1 \%$ in 1966 . Because the terrain is very complex, and the forest composed of many small stands, with the whole divided into small private land parcels, timber harvest has consisted of cutting small patches or individual trees as a market or need for the wood occurred. However, in recent years there have been larger clearcuts and some conversion of mixed forest to conifer plantations on industrial ownerships. The decline in the area of mixedwood has been counterbalanced to an unknown extent by reversion of agricultural land to mixedwood forest and by improved fire protection (Telfer 1971).

\section{Mammals}

In the 1880s Caribou Rangifer tarandus, were still common in unsettled parts of Nova Scotia (Rand 1933; Sheldon 1936). An old hunter (the late F. M. Forrest, personal communication) told me of a trip he made when he was 16 years old (that would have been in 1888) to find Caribou. Somewhere at the west side of the present day Kejimkujik National Park he found a herd on a large barren and had a good chance to observe them and to shoot a fat yearling to replenish his provisions. Within 20 years Caribou appear to have been gone from North Queens. Another old woodsman (the late E. B. Smith, Sr., personal communication) told me that when he began to guide sportsmen in the early 1900s there were still broad trails beaten though the woods in all directions in the remote parts of the District that had been made and kept open by Caribou. Sheldon (1936) also commented on the Caribou trails. By my time the Caribou were long gone and their trails had faded away before the encroaching forest. Caribou suffered from logging and burning on their winter ranges and from poorly controlled hunting. However, the probable final cause of Caribou extirpation was 
meningeal worm, Parelaphostrongylus tenuis, introduced by White-tailed Deer, Odocoileus virginianus (Benson and Dodds 1977).

The loss of a large mammal like Caribou from the regional fauna quite probably had at least minor impacts on other plants and animals living in the area. I have not been able to find any records of any observations of such impacts. However, Caribou move fast and far and feed while moving so they spread their use of vegetation out in time and space (Miller 1982). The relatively small population of Caribou in Nova Scotia would have had slight impact on other species.

Moose, Alces alces, were distributed throughout Nova Scotia and were the common game animal in my father's youth. However, after 1926 they were observed to be dying (Sheldon 1936; Benson 1958). The sick Moose exhibited symptoms similar to those later described by Anderson (1965) as resulting from infestation by the meningeal worm (Parelaphostrongylus tenuis). This organism was later found in Nova Scotia Moose by Smith et. al (1964). Parelaphostrongylus tenuis is relatively common in White-tailed Deer. It does little harm to whitetails but may cause heavy mortality among other species of the deer family (Thomas and Dodds 1988). By the 1940s, Moose were dying in large numbers from the condition which had come to be called "Moose Sickness" (Benson and Dodds 1977). The animals showed evidence of paralysis, blindness and other neurological symptoms although they were often in good physical condition otherwise. Annual reports of the Nova Scotia Department of Lands and Forests commented on the dead Moose. The 1949 report was typical, "Nearly all Rangers report moose as being in a healthier condition which is perhaps indicated by the decrease in the number of moose which were found dead. This number was 75, a decrease of 74 from last year" (Nova Scotia 1949: 65). Of course only a fraction of the dead Moose would have come to the attention of the authorities. Moose almost vanished from southwestern Nova Scotia by the 1960 s but recovered slightly following later declines in deer numbers.

Although $P$. tenuis was found in some Nova Scotia Moose in the 1960s and has been shown to cause a "moose sickness" type of illness, that does not prove that all the animals that perished in the dieoff of Nova Scotia Moose in the 1930s and 1940s died of meningeal worm infection. However, the similarity of the symptoms displayed by the sick Moose suggests that most died of the same cause. Moose have been found to suffer from neurological symptoms where no $P$. tenuis has been observed in autopsies (Tony Nette, personal communication). Those symptoms have been recently linked to deficiencies of cobalt and vitamin $B_{12}$ (Frank et al. 2004). However, it seems unlikely that a nutritional deficiency would cause a catastrophic dieoff like that reported in Moose in Nova Scotia in the 1940s, and the coincidence of the dieoff with the post-introduction boom in White-tailed Deer numbers suggests that $P$. tenuis was the principal cause.

My father was an adult before deer showed up in North Queens. They had been spreading across Nova Scotia with the help of some introductions, and by the late 1800s their numbers were increasing (Rand 1933). There were many reasons for the increase. Possibly the most decisive was the climatic warming that set in about 1850 (Hawboldt 1952; Lamb 1982). The first deer hunting season in Nova Scotia was in 1916 and by the 1930s deer were common (Sheldon 1936; Benson and Dodds 1977). Over 40000 were reported killed in Nova Scotia in one year in the early 1950 s - more than two for every square mile in the province (Benson and Dodds 1977). Deer remained numerous until the unusually severe winter of 1955-1956 caused a major dieoff of deer in western Nova Scotia. Since then they have fluctuated with winter conditions.

Beavers, Castor canadensis, were not mentioned by my father as a species that he encountered in North Queens as a young man in the 1890s and the early 1900s. The animals had been trapped almost to extirpation in Nova Scotia during the preceding century. However, in 1907 Beavers were given complete protection (Wood 1973) and the Department of Lands and Forests staff began live-trapping and transplanting them from the few remaining populations to unoccupied parts of the province.

One cold autumn dusk when I was about five years old my father took me on a short walk to a small lake where Beavers had been released. We saw a new dam blocking the outlet stream and a new house with fresh mud on it. The Beavers had made themselves at home. They soon became abundant in North Queens and remained so until after 1945. Limited trapping was allowed after that time, reducing Beaver numbers and the dense population of animals had reduced their food supply along streams and lakes. However, Beavers have continued to occur in substantial numbers in North Queens (Wood 1973).

Hunting with hounds was a favourite activity of my father and his friends. They hunted Red Foxes (Vulpes vulpes) and what they referred to as "wildcats". Most of the cats were Bobcats (Lynx rufus) but my father also described killing cats that were over six feet long from rear toes to front toes when held up by their hind legs. Those large, rangy animals were probably Lynx. More (1873) stated that there were "lucifees" (Loup cervier, Lynx) and "little lucifees" in Queens County. However, the Lynx had become rare or extirpated by the 1930s (Rand 1933; Sheldon 1936) and is now absent from the region (McCord and Cardoza 1982).

According to local tradition, there were no Striped Skunks, Mephitis mephitis, in North Queens when the area was first settled. The species is not mentioned by More (1873) who, as a land surveyor, was very familiar with the mammals of the region. It was said that 
sometime in the mid-1800s someone brought a dead, frozen animal to a local blacksmith shop. None of the farmers who happened to be there could identify it. However, a few days later someone passed who had worked in the United States and who identified it as a skunk. By my father's time skunks were common. However, by the 1930s, skunks were gone, probably due to an epidemic of distemper (Dodds 1969) but the decline in agricultural land use may also have had a negative impact on this animal of farms and forest edge. They were found in Nova Scotia only along the New Brunswick border but by the 1960s they had once again begun to spread into central areas of the province (Dodds 1969). None were present in Kejimkujik National Park in the early 1970s (Wood 1973). However, in 2001 I observed a skunk near Ten Mile Lake, in Queens County.

My father would have had difficulty in believing that the howl of the Coyote (Canis latrans) could ever be heard in North Queens. Yet in the 1970s Coyotes arrived in Nova Scotia. In North Queens, the population of White-tailed Deer in Kejimkujik National Park was apparently reduced by Coyotes which were commonly seen along Park roads and heard on still nights throughout the area (Patterson 1994). The impact of Coyotes not only on deer but on competing Red Foxes, on Snowshoe Hares (Lepus americanus), microtine rodents, grouse (Bonasa umbellus and Canachites canadensis) and other ground-nesting birds must have been considerable.

\section{Plants}

Before the arrival of White-tailed Deer, the forest floor in mature spruce-hemlock stands was carpeted with Canada Yew, Taxus canadensis. This evergreen shrub is highly palatable to deer and by the 1940s it had been eliminated from the forest. In the 1960s one experienced biologist (the late Harrison F. Lewis, personal communication) told me that the only surviving yew bush that he knew of was growing beside the outhouse at a warden cabin where one branch had grown through the wall of the well-ventilated facility and had thus escaped browsing.

One of the most important trees of North Queens is the White Pine (Pinus strobus) (Rowe 1972). White Pines were a major resource in North Queens historically (More 1873). However, in my father's time regenerating White Pine was increasingly attacked by the White Pine Weevil (Pissodes strobi). That insect kills the leaders on the top of the tree, creating crooked stems or, at worst, "cabbage trees" whose lower branches continually grow up to take the place of the weevilkilled central stem. White Pine Weevil is a native North American insect. However, the first official records of its presence in the Maritimes date from about 1920 (Martineau 1984). The insect quickly spread throughout the range of the White Pine including North Queens. The spread of the weevil was facilitated by the exten- sive areas of regenerating forest created by logging, fire and the invasion of old fields by White Pine (Belyea and Sullivan 1956). By my time the value of the White Pine resource in North Queens was greatly reduced and crooked, multi-stemmed pine occupied much space in the forest. White Pine remains an important tree in the district but the weevil attacks have reduced the value of many stems for lumber.

The American Beech, Fagus grandifolia, was common in North Queens when my father was a boy. Pure beech stands occupied the ridge tops and beech trees were also scattered throughout the hardwood and mixedwood stands. Beech nuts were always an important seasonal food source for wildlife. Black Bears (Ursus americanus), especially, sought them out for a high fat and protein food before hibernation. When whitetails arrived in Nova Scotia they quickly became the most important consumers of the dwindling supply of nuts. Loucks (1962) cited evidence that beech was formerly more common in southwestern Nova Scotia. He believed that wildfire had reduced the occurrence of the species. Early in the 1900s the Woolly Beech Scale (Cryptococcus spp.), an insect that spreads Beech Nectria Fungus (Nectria coecinea var. faginata), arrived in Nova Scotia, probably an accidental introduction from Europe (Boyce 1961). The fungus gains entry to the tree through holes made by the Woolly Beech Scale. Saunders (1970) stated that Woolly Beech Scale entered Nova Scoria from Europe about 1890 and that the fungus also entered North America through Nova Scotia in about 1929. Nectria disease debilitates beech by invading the bark and cambium, eventually killing the tree. Roland and Smith (1969: page 341) noted that "All the beech in N.S. is severely affected by the Nectria beech canker." Most beech in North Queens was unthrifty and dying by the midtwentieth century and in all cases moribund stems were thoroughly infested with Nectria cankers. Beech have declined substantially (Telfer 1971). They have been replaced by species like Sugar Maple (Acer saccharum) and Red Maple (Acer rubrum), Hemlock (Tsuga canadensis) and Red Spruce (Picea rubens).

White Birch (Betula papyrifera) and Yellow Birch (Betula alleghaniensis) were prominent trees in the North Queens forest when my father was a boy. Indeed the old farmhouse in which he was born and died was sheathed with bark of the white birch between the wallboards and the shingles. In the mid-1930s a dieback was observed in the birch (Hawboldt 1952. Mature stands all died. This phenomenon occurred all over northeastern North America.

Temperatures were high in the 1930s following a steady rise from Little Ice Age conditions that existed before the 1850s (Hawboldt 1952). One hypothetical cause of birch mortality was that the warming climate altered the species composition of the mycorrhizal flora in the soil to the detriment of species that could enter into symbiotic relationships with birch roots 
(Hawboldt 1952). Birch would thus have suffered from nutrient deficiencies. Although birch regeneration survived, live mature trees were very scarce by my time. One would have had to travel a long way to collect enough bark to sheath a house. In the 1960s I worked on forest inventories in a remote part of the District where the mature forest had formerly been dominated by a mixture of birches, Red Spruce and Hemlock (Fernow 1912), but by then the birches were rotten snags and Red Spruce, White Pine, Balsam Fir (Abies balsamifera) and Red Maple were sprouting in the gaps created by their death.

\section{Arachnids}

An invading organism that caused excitement in North Queens in the mid-twentieth century was the American Dog Tick (Dermacentor variabilis). Opinion is divided on whether the ticks were relict in a small area in Western Nova Scotia or if they were introduced. One woodsman told me of encountering ticks along a small section of the Tusket River, near the western end of Nova Scotia, during a canoe trip early in the 1900s (the late F. M. Forrest, personal communication). The distribution pattern shown by Dodds et al. (1969) suggests dispersion from an epicentre of infection. The Tusket River flows through the area of earliest distribution. By the 1930s loggers working in the western part of North Queens began to complain of tick bites. Ticks advanced on a broad front across the district in the late 1940s and the 1950s, causing consternation among the people who were unused to them. Since the 1960s, American Dog Ticks have continued to spread eastward in Nova Scotia (Andrew Hebda, personal communication).

\section{Weather}

Nova Scotia is on the track of the equatorial Atlantic hurricanes. North Queens has been occasionally lashed by at least the fringes of those storms. In 1939, the area was hit by a hurricane that blew down many trees but did limited damage in closed stands. However, in 1954, a powerful hurricane, code named "Edna", struck North Queens (Hawboldt and Bulmer 1958). Mature and old forests suffered particularly. Hurricane Edna was followed by a campaign of salvage logging as landowners tried to recover as much of the blowdown as possible. The forest openings were invaded by regeneration of Red Spruce, Red Maple, White Pine and particularly by Balsam Fir in place of the dominant Hemlock of the former stands.

\section{Prediction and Management}

Causes of some of the observed changes were natural, like birch dieback and distemper, while others were due at least in part to human intervention. There were some introductions of White-tailed Deer to Nova Scotia that probably accelerated their spread. Logging, small farming and attendant wildfires no doubt in- creased the amount of suitable habitat for deer and also the area occupied by White Pine regeneration, the habitat of the White Pine Weevil. Hunting probably hastened the extirpation of Caribou and Lynx and the near extirpation of beaver. Coyotes may have been able to invade eastern North America partly because European settlers extirpated Grey Wolves, Canis lupus, from regions to the west of Nova Scotia. Ticks and the insect vector and the fungus involved in the beech Nectria disease may have been accidentally introduced. Climatic warming over the past 150 years interacted in a complex way with other causes of ecological change.

The most important factors causing change to the terrestrial biota in North Queens operated haphazardly. Most were outbreaks of plant and animal diseases and parasites. Unpredictable outbreaks of disease are sometimes not considered to be very important by renewable resource managers simply because they are random and basically unforeseeable. Also, the education of resource managers usually focuses on other topics. However, Hurricane Edna represented another kind of random event. There was sufficient evidence of the occasional occurrence of such severe hurricanes that shrewd ecosystem managers would probably have allowed for their possible occurrence when preparing management plans.

The observed ecological changes in North Queens did not damage basic ecological functions like production, herbivory and predation. However, the suite of species involved changed. White-tailed Deer to some extent replaced Moose and Caribou as consumers while Coyotes became important predators as Lynx had been previously. After decades of absence, Beavers were brought back in numbers by deliberate management. Energy flow through the ecosystem was unimpaired but flowed through somewhat different channels. The observed changes exemplify the fluidity and unpredictability of nature (Botkin 1990).

What might have happened if, beginning in the 1890s, the forests and wildlife of North Queens had been under a modern regime of ecosystem management? Foresters might have made management plans aiming at production of a steady supply of birch logs. All would have been well for the first fifty years, then they would have found that the birch growing stock was dying and that spruce and fir were taking its place. As time went on the beech would also have been lost as a commercial species. Forest management would have had to be altered, as it indeed was following Hurricane Edna when managers were forced to revise their thinking about harvesting techniques (Johnson 1986) and deal with storm-caused openings and changes in forest composition. Conversely, the patchy nature of the storm-damaged forests provided improved habitat for White-tailed Deer and Moose.

Wildlife managers would have found a major ungulate species, the Caribou, suddenly declining. Even if the meningeal worm problem had been known, would 
managers have tried solve it by exterminating the White-tailed Deer population? Whitetails were by then spread thinly over the entire province. By the time Moose also declined there were so many deer that eradication would have been impossible. Even without parasites, how would biodiversity managers have viewed the invasion of exotic whitetails especially since they were also the culprits in the extirpation of the Canada Yew? Managers would have been largely helpless to protect the yew except possibly by fencing small reserved patches. Although "ecosystem" preservation is often a suitable management approach to maintain threatened species, it would have been counterproductive in this case because old hemlock/spruce forest is preferred winter habitat for whitetails as well as the site of best yew growth (Schierbeck 1931). Lynx still remain on Cape Breton Island so protection from hunting might have been adequate to recover the species on the mainland of Nova Scotia as it did for the Beaver. Because skunks appear to have died from distemper, reintroduction of healthy animals following the dieoff might also have re-established viable populations and prevented local extirpation.

Our hypothetical ecosystem managers would have emerged from the hundred-year period somewhat battered. They would have lost a member of the charismatic megafauna, the Caribou. They would no doubt have been chagrined by the fact that the district had been overrun by the exotic White-tailed Deer and Coyotes, not to mention the obnoxious dog ticks. Some major tree species would also have been drastically reduced. However, a major understorey shrub and two mammal species might have been rescued and one mammal species, the Beaver, was indeed returned to the area by management. Would the public consider that money spent trying to maintain the ecosystems as they were in the 1890 s to have been well spent as part of a worthwhile effort to "preserve" "nature" in the region? Or would managers simply be seen as having cast themselves in front of the juggernaut of inevitable ecological change?

In the 1890 s the coming changes and their impact could not have been foreseen. If managers at that time had set goals like doubling the sustainable harvest of White Birch and developing an industry to use it, or if they had set out to double the Caribou population to satisfy outfitters, they would have been in for a rough time. Yet, such factory-type production goals are often set in resource management.

This example highlights the significance of scale in biodiversity conservation. Would it have been worthwhile to try to keep species that are still common elsewhere in North America, like Caribou, Lynx, Striped Skunks, and Canada Yew, in the district or even in Nova Scotia? At what price should we try to keep everything that was present historically in a local or regional biota? Or should the waxing and waning of species' ranges be accepted as inevitable?
Although such a comprehensive management approach would have been unthinkable in the 1890s, a program of adaptive management (Walters 1986) would have been appropriate. With the adaptive model in mind, managers might have been aware of the likelihood of natural variability and therefore cautious in goal setting. They could have initiated a program of monitoring that might have picked up changes in species status in their early stages when some prediction of the magnitude of upcoming impacts could have been made. While little could have been done to change the course of events in the short term, a more comprehensive and quantitative understanding of the operation of nature might have led to effective interventions later on.

The haphazard nature of the changes in the ecology of North Queens during the past hundred years underlines the difficulty of predicting what will happen next in nature. One is reminded of the soldier's axiom regarding shellfire, "You won't hear the one that gets you". The example of North Queens demonstrates the inevitability of environmental change and emphasizes the value of a flexible approach to forest and wildlife management.

\section{Literature Cited}

Anderson, R. C. 1965. Cerebrospinal nematodiasis (Pneumostrongylus tenuis) in North American cervids. Transactions of the North American Wildlife and Natural Resources Conference 30: 156-167.

Belyea, R. M., and C. R. Sullivan. 1956. The white pine weevil: a review of current knowledge. Forestry Chronicle 32: 58-67.

Benson, D. A. 1958. Moose "sickness" in Nova Scotia - 1 . Canadian Journal of Comparative Medicine 22: 244-248.

Benson, D. A., and G. D. Dodds. 1977. The deer of Nova Scotia. Department of Lands and Forests, Province of Nova Scotia. 92 pages.

Botkin, D. B. 1990. Discordant harmonies - a new ecology for the twenty-first century. Oxford University Press, New York. 241 pages.

Boyce, J. S. 1961. Forest pathology, $3^{\text {rd }}$ edition. McGrawHill Book Company, New York. 572 pages.

Canada. 1871. Census of Canada 1870-71. Ministry of Agriculture, Ottawa (5 volumes).

Dodds, D. G. 1969. The striped skunk, Mephitis mephitis (Schrieber), in Nova Scotia. Canadian Field-Naturalist 83: 229-233.

Dodds, D. G., A. M. Martell, and R. E. Yescott. 1969. Ecology of the American dog tick, Dermacentor variabilis (Saq) in Nova Scotia. Canadian Journal of Zoology 47: 171-181.

Fernow, B. E. 1912. Forest conditions in Nova Scotia. Commission of Conservation, Ottawa. 93 pages plus maps.

Frank, A., J. McPartlin, and R. Danielsson. 2004. Nova Scotia moose mystery - a moose sickness related to cobalt and vitamin $\mathrm{B}_{12}$ deficiency. The Science of the Total Environment 318: 89-100.

Hawboldt, L. S. 1952. Climate and birch "dieback". Department of Lands and Forests, Province of Nova Scotia. Bulletin 6. 37 pages. 
Hawboldt, L. S., and R. M. Bulmer. 1958. The forest resources of Nova Scotia. Nova Scotia Department of Lands and Forests. 171 pages.

Johnson, R. S. 1986. Forests of Nova Scotia - a history. Nova Scotia Department of Lands and Forests and Four East Publications. Halifax. 407 pages.

Lamb, H. H. 1982. Climate, history and the modern world. Methuen, London. 387 pages.

Loucks, O. L. 1962. A forest classification for the Maritime Provinces. Forest Research Branch. Reprinted from the Proceedings of the Nova Scotian Institute of Science 25: Part 2, 1959-60.

Martineau, R. 1984. Insects harmful to forest trees. Multiscience Publications Limited and the Canadian Forestry Service. 261 pages.

McCord, C. M., and J. E. Cardoza. 1982. Bobcat and lynx. Pages 728-766 in Wild mammals of North America. Edited by J. A. Chapman and G. A. Feldhamer. Johns Hopkins University Press. 1147 pages.

Miller, F. L. 1982. Caribou. Pages 923-959 in J. A. Chapman, and G. A. Feldhamer, Wild mammals of North America. Edited by Johns Hopkins University Press. 1147 pages.

More, J. F. 1873. The history of Queens County, N.S. Nova Scotia Printing Company, Halifax. [Facsimile edition by Mika Studio, Belleville, Ontario, 1972]. 250 pages.

Nova Scotia. 1966. Nova Scotia Forest Inventory - Lunenburg Subdivision, Counties Lunenburg, Queens. Nova Scotia Department of Lands and Forests, Forestry Division Inventory Section. 36 pages plus tables.

Nova Scotia. 1949. Report of the Department of Lands and Forests, 1949. King's Printer, Halifax Nova Scotia. 96 pages.

Patterson, B. R. 1994. Surplus killing of White-tailed Deer, Odocoileus virginianus, by Coyotes, Canis latrans, in Nova Scotia. Canadian Field-Naturalist 108: 484-487.
Rand, A. L. 1933. Notes on the mammals of the interior of western Nova Scotia. Canadian Field-Naturalist 47: 4160.

Roland, A. E. 1982. Geological background and physiography of Nova Scotia. Nova Scotia Institute of Science, Halifax. 311 pages

Roland, A. E., and E. C. Smith. 1969. The flora of Nova Scotia. The Nova Scotia Museum. 743 pages.

Rowe, J. S. 1972. Forest regions of Canada. Department of the Environment, Canadian Forest Service Publication 1300. 172 pages plus map.

Saunders, G. L. 1970. Trees of Nova Scotia. Bulletin 37, Nova Scotia Department of Lands and Forests. 102 pages.

Schierbeck, O. 1931. Forestry vs. game cover. Canadian Field-Naturalist 45: 28-30.

Sheldon, C. 1936. The mammals of Lake Kedgemakooge and vicinity, Nova Scotia. Journal of Mammalogy 17: 207-215.

Smith, H. J., R. McG. Archibald, and A. H. Corner. 1964. Elaphostrongylosis in Maritime moose and deer. Canadian Veterinary Journal 5: 287-296.

Telfer, E. S. 1971. Changes in carrying capacity of deer range in western Nova Scotia. Canadian Field-Naturalist 85: 231234.

Thomas, J. E., and D. G. Dodds. 1988. Brainworm, Parelaphostrongylus tenuis, in moose, Alces alces, and whitetailed deer, Odocoileus virginianus, of Nova Scotia. Canadian Field-Naturalist 102: 639-642.

Walters, C. 1986. Adaptive management of renewable resources. Macmillan Publishing Company, New York.

Wood, T. J. 1973. The recent mammals of Kejimkujik National Park. Proceedings of the Nova Scotia Institute of Science 27: 43-58 (1971-1973).

Received 15 February 2002

Accepted 24 June 2004 